\title{
Developing a Strategic Perspective for Construction Industry in Botswana
}

Joseph Ssegawa, (University of Botswana, Botswana)

The paper documents the outcome of a study conducted to formulate the strategic perspective of the construction industry in Botswana. The study was sanctioned by the two influential entities namely the Ministry of Infrastructure and BOCCIM Construction Sector. The two entities not only represent the demand and supply side of the construction industry but also represent key professions, trades and interests of the industry. A focus group approach was used based on workshops to formulate the strategic perspective. Workshop participants were drawn from various organisations that play a role in the delivery of construction projects. Individually they also represented the various professions, trades, occupations and interests relating to the construction processes in Botswana. Specific statements for industry's vision, mission, values and goals were formulated through constructive discussions and debates to describe the future desired state of the construction industry. These are to serve as guiding tools for the industry's reform process. The paper provides a step by step approach that integrates several scholastic frameworks for developing a strategic perspective for the industry.

Keywords: Construction, Development, Vision, Mission, Strategic, Reform

\section{Introduction}

Botswana is located in the southern part of Africa and covers an area of $582,000 \mathrm{Km}^{2}$. In 2011 , its population was estimated at 2.1 million inhabitants (Statistics Botswana, 2012a). Botswana is an upper middle income country with a per capita gross domestic product (GDP) of about USD\$ 6,530 (Statistics Botswana, 2012a). The economy has grown at an average annual growth rate of over 8\% since independence in 1966 and is dominated by the mining sector which contributes on average about $40 \%$ of GDP. Construction projects have been financed from revenues obtained mainly from diamonds sales.

Like most construction industries of all nations, the construction sector has played an important role in the social and economic development of Botswana. Though its annual contribution to GDP has dropped from the 1990s level that ranged between 6-9\% to the current levels of between $4-7 \%$, it is nevertheless high when compared to some of the sub-Saharan countries. In 2012, for example, construction industry's contribution to GDP was estimated at US\$237 million constituting $6.7 \%$ of total GDP (Statistics Botswana, 2012a). In addition, the sector employed $6.1 \%$ of the national total labour force which stood at 378,877 in 2011 (Statistics Botswana, 2012b).

A number of studies (e.g. Turin, 1973; Wells, 1985; Ofori, 1988; Hillebrandt, 2000) have linked the performance of the construction industry with the growth of the economy. This has created a concern among scholars, practitioners and policy makers about the performance of sector especially when, for example, it delivers project below expected quality, with recurrent cost or time overruns. As a result, reports have surfaced from various corners of the world (e.g. World Bank, 1984; and ILO, 1991) identifying challenges which are generic and specific to construction industries around the world. Some reports (e.g. Fox and Skitmore, 2007) have also 
strategized ways of overcoming constraints in order to enhance the long-term performance of the industry. In some instances the underperformance of the industry has often triggered reforms in the sector. A good example is the British construction industry in the early 1990s. The sector was riddled with a number of challenges including the lack of effective leadership, customer focus, health and safety and a high level of litigations (Latham, 1994). Construction stakeholders in Britain called for reforms that led to various studies. Most notable output of the studies are the famous Latham (Latham, 1994) and Egan (1998) Reports. Construction industry reform has not been limited to the British industry. Various countries have pursued reforms aimed at enhancing the long-term performance of the sector and these include, for example, Tanzania in 1981 (NCC, 2001), Singapore in 1984 (CIDB Act, 1984), Malaysia in 1994 (CIDB, 1994) and South Africa in 2000 (SA CIDB Act, 2000).

Botswana has also been in the process of reforming its construction industry as a result of the declining performance over the last two decades. The efficiency and effectiveness of the industry has declined as a result of a number of challenges (Palalani, 2000; Piet, 2011). The industry is besieged by a number of problems whose symptoms have surfaced in form of late delivery of projects, cost escalations and a number of poor quality facilities being delivered to clients (e.g. Thomas et al., 2005; Ramadubu, 2010). In addition, there has been an increased perception of increased corruption in the procurement process in the sector (Mmegi, 2008). The paper therefore, reports a study undertaken, to formulate the strategic perspective as part of the reform process of the construction industry in Botswana.

\section{The Context of the Strategic Perspective in the Reform Process}

In trying to reform an industry a few points are noteworthy. Reform is a lengthy and often a protracted process that requires negotiations and consensus building among stakeholders (Loosemore, 2003). It is not a linear but a cyclic process with several intermittent phases. Furthermore, the manner in which the reforms are carried out differs from country to country. However, most reforms take the form of a study that produces recommendations; followed by formulation of a policy/master plan; enactment of legislation; establishment of an institutional framework; and implementation of reform programmes. Botswana considered the strategic perspective as one of the guiding tools for an effective reform process.

The reform process in Botswana was triggered by frequent cost escalations, late delivery of projects, and sometimes abandonment of projects by contractors. The reform process was initiated based on a four-phase strategic planning model (Baker, 2007 and Pearce, 2009) with four key questions to be answered by each phase shown Table 1. An answer to each question invokes a specific objective and outcome for each phase.

\begin{tabular}{|l|l|l|}
\hline Phase & \multicolumn{1}{|c|}{ Question } & \multicolumn{1}{|c|}{ Objective } \\
\hline One & Where is the industry now? & $\begin{array}{l}\text { To conduct a situation analysis to ascertain the } \\
\text { current state of the industry. }\end{array}$ \\
\hline Two & $\begin{array}{l}\text { Where should the industry be in } \\
\text { future? }\end{array}$ & $\begin{array}{l}\text { To develop a strategic perspective reflecting the } \\
\text { future desired state of the industry. }\end{array}$ \\
\hline Three & $\begin{array}{l}\text { How shall the industry get to the } \\
\text { future desired state? }\end{array}$ & $\begin{array}{l}\text { To develop and implement a road map for reforming } \\
\text { the industry in order to achieve the desired state of } \\
\text { the industry }\end{array}$ \\
\hline Four & $\begin{array}{l}\text { How shall we know the industry is } \\
\text { getting to or has got to the future } \\
\text { desired state? }\end{array}$ & $\begin{array}{l}\text { To develop and implement a monitoring and } \\
\text { evaluation (M\&E) system to assess the impact of } \\
\text { reforms on the performance of the industry }\end{array}$ \\
\hline
\end{tabular}

Table 1 The four phase model used in reforming the construction sector

Ssegawa, J (2013) 'Developing a strategic perspective for construction industry of Botswana', Australasian Journal of Construction Economics and Building, 13 (3) 157-172 
Phase one of the reform model answers the question: Where is the industry now? The main objective of the phase was to conduct a situational analysis to determine the status of the industry, in terms of current and future challenges faced by the industry and how they impact on its performance. Phase one was completed in 2011 and its results are reported in Ssegawa, Ntshwene and Ngowi (2013). In summary, the outcome of the phase indicated that the cause of decline in performance of the industry emanated from the poor decisions and inappropriate actions pursued by project owners (and their representatives); suppliers of services and resources to projects (e.g. consultants, contractors, etc.); and other stakeholders connected to the delivery of projects (e.g. utility companies, land boards, etc.). In addition, it was noted that the construction business environment was not conducive for project delivery because, among others, it was found to be uncoordinated, fragmented, unregulated and lacked leadership to provide a strategic direction.

Phase two (the subject of this paper) aimed at galvanising stakeholders to answer the question: Where do we want the industry to be in future? The answer to the question was to develop a suite of strategic statements that stakeholders collectively perceive to represent the future desired state of the industry, one which differs from the prevailing situation.

Phase three (which is currently being completed) aimed at developing and implementing a road map to guide the reform process by answering the question: How shall the industry get to the future desired state? The phase is crucial as it requires implementing a number of subprocesses including, benchmarking with countries that have successfully reformed their industries; mapping and realigning current organisational mandates; analysing, amending and formulating legislation; creating new institutions; and planning and implementing programmes to reform the sector.

Phase four aims at developing and implementing an assessment system to answer the question: How shall we know the industry is getting or has got to the future desired state? This requires developing a monitoring and evaluation (M\&E) system to assess the progress of reforms.

\section{Literature on Developing a Strategic Perspective}

For any reform process to be relevant stakeholders should collectively have a clear picture of what constitutes the future desired state of the industry - what is termed here as the strategic perspective. Various authors (e.g. Baker, 2007; Ansoff, 2007) have intimated that a strategic perspective of an industry requires answering four key questions indicated in Table 2 . The answer to each question leads to a breakdown of the strategic perspective into the mission, vision, values and goals statements (Baker, 2007).

\begin{tabular}{|l|l|}
\hline \multicolumn{1}{|c|}{ Question } & Statement \\
\hline What is the business of the industry? & Mission \\
\hline How does the industry want to excel in the defined business? & Vision \\
\hline How should the industry stakeholders conduct themselves while conducting business? & Value \\
\hline What are the key issues that industry should address to excel in business? & Goal \\
\hline
\end{tabular}

Table 2 Questions leading to the identification of Agenda components

Before discussing the nature of each statement a few points are worth noting. First, in the literature most statements are discussed at an organisational level and rarely at a macro level (Wong, $\mathrm{Ng}$ and Chan, 2009). The study adapted the concepts to a macro level. Second, there is a constant debate in literature about the usefulness of such statements in enhancing performance (Kemp and Drewer, 2002). This has arisen because there has been no definitive empirical evidence linking existence of strategic statements to performance. However, cognitive

Ssegawa, J (2013) 'Developing a strategic perspective for construction industry of Botswana', Australasian Journal of Construction Economics and Building, 13 (3) 157-172 
benefits have been identified by a number of authors (e.g. Baetz and Bart, 1996; Bartkus, Glassman and MacFee, 2004; Matejka, Kurke and Gregory, 1993). Third, it is difficult to find a common definition in literature for each statement. The paper therefore, focuses on the purpose and components that constitute each statement. The two attributes were useful in guiding the industry stakeholders during the formulation of the statements.

\section{Mission Statement}

David (1989) noted that a mission statement is critical to defining the strategic perspective of a sector. A mission statement offers the sector an opportunity to define what the uniqueness of its business (Kemp and Dwyer, 2003; and Davies and Glaister, 1997). Matejka, Kurke and Gregory (1993: 34) noted that mission statement 'melds the inspiration of the vision - what we want to become - with the realities of who we are, what we do, and for whom'. Campbell and Yeung (1991) further noted that it is an important tool to communicate the direction and purpose of the sector to the stakeholders. It also provides a framework for policy makers especially during nonroutine decisions (Bartkus, Glassman and MacFee, 2004).

\begin{tabular}{|l|l|}
\hline \multicolumn{1}{|c|}{ Mission component } \\
\begin{tabular}{|l} 
(Source: Pearce and David, \\
1987; David, 1989)*
\end{tabular} & $\begin{array}{l}\text { Brief explanation and what it implies in the construction industry } \\
\text { (Source: Morris, 1996; and Kemp and Dwyer, 2003; additional } \\
\text { interpretation for the sector by the authors in italics) }\end{array}$ \\
\hline 1.Customers & $\begin{array}{l}\text { Defining the nature or identity of current and future customers or markets } \\
\text { e.g. what are customers of the construction industry? Is it the national } \\
\text { economy, region or global outreach? }\end{array}$ \\
\hline 2.Principal offering & $\begin{array}{l}\text { Need satisfied; services or products offered. Construction generally } \\
\text { involves several services e.g. design, construction, maintenance, } \\
\text { demolition, etc. Should all services be listed in the mission statement or } \\
\text { an all-embracing word could be used e.g. infrastructure, etc.? }\end{array}$ \\
\hline 3.Geographical domain or \\
market & $\begin{array}{l}\text { Geographical location where customers are found e.g. nation, region or } \\
\text { world. Where does a particular construction industry operate? Is it } \\
\text { national or regional (including future prospects)? Care must be taken not } \\
\text { to confuse component } 1 \text { and 3. }\end{array}$ \\
\hline 4.Core technology & $\begin{array}{l}\text { The technological platform or change on which business is anchored. } \\
\text { What unique technology platform does the industry use worth } \\
\text { pronouncing? This may not be applicable to the construction industry as } \\
\text { its technology has not changed that much especially in developing } \\
\text { countries where construction is still labour intensive }\end{array}$ \\
\hline 5.Survival, growth \& \\
profitability
\end{tabular}

Table 3 Suggested items in a mission statement

Ssegawa, J (2013) 'Developing a strategic perspective for construction industry of Botswana', Australasian Journal of Construction Economics and Building, 13 (3) 157-172 
In writing a mission statement, the framework of Pearce and David (1987) and David (1989) provided a useful starting point for identifying components to incorporate in the statement. The framework is based on nine components shown in Table 3. A brief explanation of each component is provided from the work of Morris, 1996; and Kemp and Dwyer (2003) and how it may be contextualised in the construction industry (see column two and three of Table 3 ).

A few points may be noted about the framework. Campbell and Yeung (1991) noted that a mission statement must be action oriented. Organisations have operationalised the concept by starting the mission statement with the word 'to', followed by an action verb, for example, 'to build, develop, regulate, etc. ...' They further noted that a mission statement may become 'mission impossible' if it is too long as it is not internalised by stakeholders and hence not serving the intended purpose. The challenge therefore is to select an optimal number of components.

Based on that premise, Campbell and Yeung (1991), suggested that a mission statement should have four basic components from the Table 3 namely (not in any particular order): customer served; principal offering or products/services offered; geographical domain of operation, and an extra but optional component i.e. from any of the components 4 up to 9 in Table 3. They suggested that the latter should uniquely capture the nature of the industry, for example, be it a concern for survival, growth, profitability; safety, health and environment or technology prowess.

\section{Vision Statement}

A vision statement describes the strategist dream of success. It describes how stakeholders perceive success when the 'mission' is accomplished (Matejka, Kurke and Gregory, 1993). Its objective is to align, inspire and motivate stakeholders into having a shared sense of purpose that puts the industry's goals above self-interest (Bennis and Nanus, 1985). Table 4 provides a guideline for formulating an effective vision statement.

\begin{tabular}{|c|c|}
\hline Vision component & Explanation (added by authors in italic) \\
\hline $\begin{array}{l}1 \text { The strategist or 'dreaming' must } \\
\text { identify itself }\end{array}$ & $\begin{array}{l}\text { The entity dreaming could be the construction or building } \\
\text { industry or sector }\end{array}$ \\
\hline $\begin{array}{l}2 \text { Dream must be stated with a } \\
\text { future orientation including date } \\
\text { of realisation }\end{array}$ & $\begin{array}{l}\text { The phraseology must depict the dream as a future event - the } \\
\text { commonly used phrases are 'to be...' It is also becoming } \\
\text { common to put a date when the dream will be realised (e.g. 'by } \\
\text { the end of } 2020 \text { or } 2025 \text {, etc.'). }\end{array}$ \\
\hline $\begin{array}{l}3 \text { The dream, excellence or } \\
\text { success must be stated and } \\
\text { moreover in measurable terms }\end{array}$ & $\begin{array}{l}\text { How excellence or success will be judged e.g. leader, best, } \\
\text { renowned, number one, most efficient, etc. Most often stated in } \\
\text { relative terms by comparing with competitors }\end{array}$ \\
\hline $\begin{array}{l}4 \text { State the business and } \\
\text { geographical domain in which } \\
\text { the excellence will be judged }\end{array}$ & $\begin{array}{l}\text { This requires stating the nature of the business of industry (e.g. } \\
\text { airline, research centre, construction industry, etc.) and where it } \\
\text { operates - geographical domain (e.g. in the region, world, in } \\
\text { Africa, in country, etc.) }\end{array}$ \\
\hline
\end{tabular}

Table 4 Suggested items in a vision statement

Source: Kaplan, Norton and Barrows (2008) and Bennis and Nanus (1985)

\section{Value Statement}

A value statement is a list of carefully selected words that communicate the principles, ethos, beliefs and expected behaviours of the industry's stakeholders (Armstrong, Harker, Kotler and Brennan, 2009). The statement defines the value system of the stakeholders by providing a

Ssegawa, J (2013) 'Developing a strategic perspective for construction industry of Botswana', Australasian Journal of Construction Economics and Building, 13 (3) 157-172 
yardstick for judging decisions, attitudes, conduct and actions appropriate for keeping the image of the sector (Bennis and Nanus, 1985). Desmidt, Prinzie and Decramer (2011) provided a guideline for formulating a value statement based on three groups namely protected, core and created values as illustrated in Table 5.

\begin{tabular}{|l|l|l|l|}
\hline Value & Suitable for & \multicolumn{1}{|c|}{ Examples } & Instrument for 'enforcing' \\
\hline Protected & $\begin{array}{l}\text { Value } \\
\text { statement }\end{array}$ & $\begin{array}{l}\text { Concern for health, safety, quality, } \\
\text { environment, corruption and rights. }\end{array}$ & $\begin{array}{l}\text { Rules, standards, certification, } \\
\text { and have zero-tolerance to } \\
\text { infringement }\end{array}$ \\
\hline Core & $\begin{array}{l}\text { Value } \\
\text { statement }\end{array}$ & $\begin{array}{l}\text { Integrity, honest, diversity, } \\
\text { openness, fairness, respect, } \\
\text { empathy, conscientiousness and } \\
\text { zeal. }\end{array}$ & Code of conduct \\
\hline Created & Goal Statement & $\begin{array}{l}\text { Profitability, market share, image, } \\
\text { social responsibility and } \\
\text { innovativeness }\end{array}$ & $\begin{array}{l}\text { Organisational or sector goals } \\
\text { and objective statements }\end{array}$ \\
\hline
\end{tabular}

Table 5 Value system taxonomy

Source: adapted from Desmidt, Prinzie and Decramer (2011)

Protected values have a zero-tolerance for infringement and are normally protected internally or externally by rules, standards, regulations or legislation. Core values define the character and attitude of stakeholders. These are normally enforced by an instrument in the form of a code of conduct. It is common that a value statement may emphasise a value that is already embedded in the legislation e.g. a stance on corruption may also have an existing anti-corruption legislation.

\section{Goal Statement}

Desmidt, Prinzie and Decramer (2011) noted that goal statement is a created and voluntary set of values that the industry stakeholders develop to foster a common benefit (see examples in Table 5). They are broad statements which are achievable in the long-term and describe the major undertakings required to pursue the mission and achieve the vision.

\begin{tabular}{|c|c|}
\hline Component (or goal) & $\begin{array}{l}\text { Expected outcome and possible means of achieving the outcomes } \\
\text { (contextualisation to the construction industry by authors in italic) }\end{array}$ \\
\hline 1. Directed at Government & $\begin{array}{l}\text { Committed support for the sector from government e.g. advise, } \\
\text { collaborate and advocate for government to pursue constructive policies } \\
\text { on training, procurement, regulations, etc. }\end{array}$ \\
\hline $\begin{array}{l}\text { 2. Directed at business } \\
\text { environment }\end{array}$ & $\begin{array}{l}\text { Institutional support to provide a well-coordinated, organised, dynamic } \\
\text { and viable sector e.g. identify institution(s) to provide leadership, } \\
\text { coordination, facilitation, forum for discussion, etc. }\end{array}$ \\
\hline 3. Directed at customer & $\begin{array}{l}\text { Increased customer satisfaction during project delivery e.g. provide } \\
\text { predictability of time, cost, quality, functionality, etc. }\end{array}$ \\
\hline $\begin{array}{l}\text { 4. Directed at sector } \\
\text { processes }\end{array}$ & $\begin{array}{l}\text { Increased productivity in sector e.g. service providers to use innovative } \\
\text { ideas, methods, materials, techniques, ICT, R\&D, that are sustainable, } \\
\text { etc. }\end{array}$ \\
\hline $\begin{array}{l}\text { 5. Directed at learning and } \\
\text { growth }\end{array}$ & $\begin{array}{l}\text { Adequate, skilled, professional, ethical, employable and entrepreneurial } \\
\text { workforce e.g. facilitate or educate, train, regulate, certify, mentor, offer } \\
\text { apprenticeship and require continuous professional development, etc. }\end{array}$ \\
\hline
\end{tabular}

Table 6 Components forming a goals statement

Source: Kaplan and Norton (1996); Fox and Skitmore (2007); Ofori (1994); and Porter (1990)

Ssegawa, J (2013) 'Developing a strategic perspective for construction industry of Botswana', Australasian Journal of Construction Economics and Building, 13 (3) 157-172 
To develop a guiding framework for formulating a goal statement, the balanced scorecard model (Kaplan and Norton, 1996) was used as starting point. Three of its four perspectives (for consistency referred to as components) namely, customer, processes and learning and growth were adopted for inclusion in the goal statement. The financial component was deemed useful at an organisational level but not for the sector. It was hence replaced by government and business environment components, identified from the work of Fox and Skitmore (2007) and Ofori (1994) (based on adaptation of Porter's Diamond model). Fox and Skitmore (2007) emphasised that government is instrumental in developing a well organised, coordinated and dynamic construction industry. Together with the private sector, government can create an environment conducive to construction business. Giang and Pheng (2011) also asserted that institutional support facilitates the creation of a competitive business environment which in turn develops an innovative and effective construction industry. Table 6 provides the five identified components that guided the formulation of the goal statement including possible outcomes.

\section{Methodology}

Formulating a strategic perspective requires a participatory process that involves as many stakeholders as possible to achieve the required buy-in and ownership of the outcome. Participation requires stakeholders to debate, discuss and adopt a strategic perspective based on consensus. Inclusiveness means reaching out to various groups of stakeholders in order to balance interests that are reflected in the strategic perspective. Therefore, the process should not be conducted as an experiment, in a secluded office, by a think tank of consultants that emerge later, with a blue print for the industry.

\section{Study Oversight}

The study was strategically managed by a task force made up of 25 members representing Botswana Confederation of Commerce Industry and Manpower (BOCCIM) - Construction Sector and the Ministry of Infrastructure Science and Technology (MIST). BOCCIMConstruction Sector consists of an amalgamation of private sector organisations representing professional and trade associations and regulation boards in the construction sector, labour unions, private developers, parastatals and non-governmental organisations. MIST was mandated by the government to represent its interest in the reform process.

Operationally, the study was driven by group of researchers commissioned by the task force to carry out a three-stage process namely literature review, workshop and conference stage as illustrated in Figure 1.As a quality assurance measure, the output of each stage was vetted by the task force before being accepted.

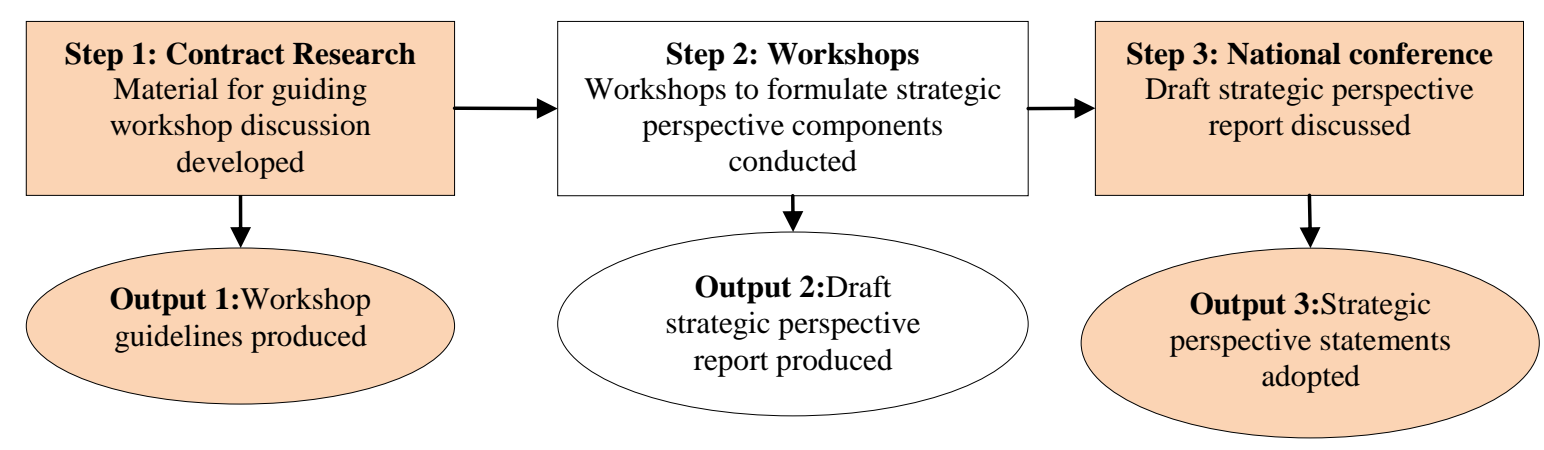

Figure 1 Steps used in the research process

Ssegawa, J (2013) 'Developing a strategic perspective for construction industry of Botswana', Australasian Journal of Construction Economics and Building, 13 (3) 157-172 


\section{Literature Research Stage}

Researchers conducted literature review to provide background materials that explained, simplified and guided stakeholders during the formulation of the statements for the strategic perspective of the industry. These have been briefly presented in Section 2 and 3 of the paper.

\section{Workshop Stage}

Stage two was based on a focus group research approach. Focus group is a qualitative research approach where a group of people with a deep interest, knowledge or experience on the subject of investigation are brought together to discuss their perceptions, opinions, beliefs and ideas in order to come to some form of consensus on an issue (Blumberg, Cooper and Schindler, 2005). The approach was chosen against other qualitative research methods such as questionnaires and interviews because of its suitability in involving stakeholders in the discussion leading to the formulation of the strategic perspective. Blumberg, Cooper and Schindler (2005) further suggested that an effective focus group should consist of six to twelve participants. The latter (12) was considered the appropriate number for maximum involvement of industry stakeholders. Seven locations representing key catchment towns of Botswana shown in Table 7 served as venues for the workshops.

\begin{tabular}{|l|c|c|c|c|}
\hline \multirow{2}{*}{ Venues } & Workshops (No.) & \multicolumn{3}{|c|}{ Participants } \\
\cline { 3 - 5 } & & Invited (No.) & Attended (No.) & Ratio (\%) \\
\hline Francistown & 7 & 84 & 80 & $95 \%$ \\
\hline Ghanzi & 1 & 12 & 12 & $100 \%$ \\
\hline Kang & 1 & 12 & 11 & $92 \%$ \\
\hline Gaborone & 9 & 108 & 101 & $94 \%$ \\
\hline Kasane & 2 & 24 & 24 & $100 \%$ \\
\hline Kanye & 2 & 24 & 22 & $92 \%$ \\
\hline Maun & 3 & 36 & 31 & $86 \%$ \\
\hline Total & 25 & 300 & 281 & $94 \%$ \\
\hline
\end{tabular}

Table 7: Location and number of workshops held

\begin{tabular}{|l|l|}
\hline \multicolumn{1}{|c|}{ Groups } & \multicolumn{1}{c|}{ Stakeholder sub-groups } \\
\hline Project Clients & $\begin{array}{l}\text { Central government departments, local authorities, parastatals and } \\
\text { private developers. }\end{array}$ \\
\hline Project Suppliers & $\begin{array}{l}\text { Quantity surveyors, engineers, architects, landscapers, contractors, } \\
\text { material suppliers associations, foremen/women, etc. }\end{array}$ \\
\hline $\begin{array}{l}\text { Project Processes } \\
\text { Regulators }\end{array}$ & $\begin{array}{l}\text { Central government departments (e.g. procurement, health and safety, } \\
\text { tax, finance, training, certification, building regulators, standards), } \\
\text { professional boards, etc. }\end{array}$ \\
\hline Facilitators & $\begin{array}{l}\text { Training institutions, Ministry of Finance and Development Planning, } \\
\text { Ministry of Local Government, etc. }\end{array}$ \\
\hline
\end{tabular}

Table 8 The various groups of stakeholders invited to workshops

A schedule of 25 half-day workshops was drawn up and conducted between June and November, 2011. Participants in the workshops were drawn from four groups namely project client, supplier, regulator and facilitator organisations as shown in Table 8. Hegazy (2002) noted these groups of stakeholders play a key role in project delivery in the sector. Each of the four

Ssegawa, J (2013) 'Developing a strategic perspective for construction industry of Botswana', Australasian Journal of Construction Economics and Building, 13 (3) 157-172 
stakeholder groups was responsible for selecting three people for each workshop to make the required total of 12 participants. A total of 300 participants were invited and 281 (94\%) turned up (see Table 7). A workshop programme and guideline materials were sent to participants for reading prior to attending the workshops. The workshop sessions were managed by three facilitators (part of the research the group); one person was dedicated to the facilitation, another for recording the proceedings, while the third provided quality assurance by assisting in the two tasks. There were four sessions, the first explained statements, associated components and guidelines on how to formulate the statements; the second session allowed participants to formulate the statements - mission, vision, values and goals specific to the construction industry in Botswana. In this session, participants were divided in four groups of three people (but not from the same stakeholder group). The third session allowed each group to present the outcome of their task. The final session was aimed at reaching a consensus on each statement of the strategic perspective. At the end of each workshop, a summary report was presented to participants for correction and confirmation.

After the last $\left(25^{\text {th }}\right)$ workshop, a draft report capturing the proceedings of all workshops was compiled. Due to the number of formulations made by each workshop group, a content analysis was undertaken to identify the five most cited statements. The outcome was consolidated and presented as the draft report for the conference delegates. Each workshop transcript was also presented as an appendix to the draft report to enable other participants to read the various workshop discussions.

\section{Conference Stage}

A one-day national conference was held in December 2011 and was necessitated by two issues. First, each groups of workshop participants never got to know the specific statements formulated by their counterparts. Second, there was a need to involve more stakeholders beyond workshops. Invitations were therefore, sent to 550 delegates of which 512 attended the one-day conference.

The conference had five sessions with first providing a background to the study and the reform process of the industry. The second session was a presentation by the chief executive officer of the South African Construction Industry Development Board (CIDB). The presentation highlighted the processes that the South Africa construction industry went through to establish the CIDB and the impact it has had on the construction industry landscape. The draft report was then presented in the third session after which discussions and adoption of each strategic statement proceeded in the fourth session. The last session brainstormed on how to carry the reform process forward.

\section{Formulating the Strategic Perspective Components}

The strategic statements discussed below were adopted by the consensus built in the national conference. Each statement is also discussed in terms of how it complied with the guidelines identified from literature (Section 3). The context in which the components were adopted is discussed to highlight the thinking, debates and discussions that preceded each adoption.

\section{Formulated Mission Statement}

The mission statement shown in Figure 2 was adopted based on Campbell and Yeung (1991)'s four item model (see section 3.1). The thinking behind the choice of words in the statement was given as follows. 


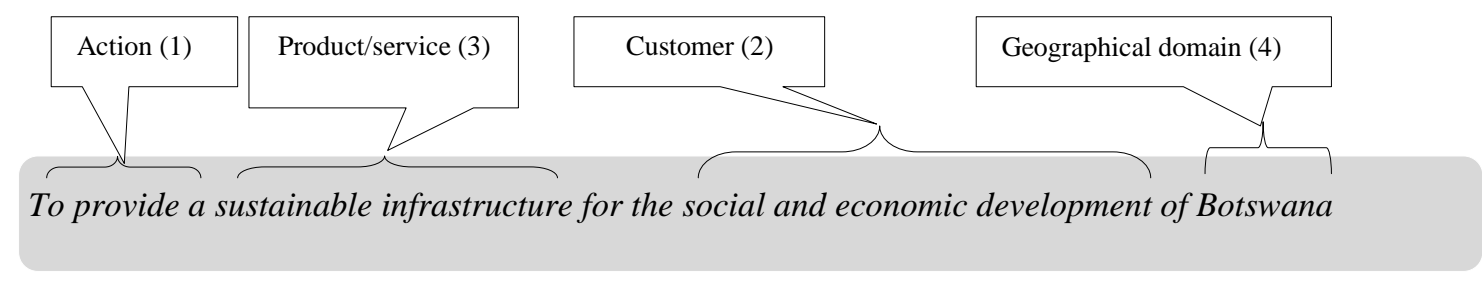

Figure 2 Formulated mission statement for the sector

First, the phrase 'to provide' (see label 1 in Figure 2) was construed as verb that connotates action and direction in line with the expectation of a mission statement. There was however, a debate as to whether the phrase 'to develop' was more appropriate than 'to provide'. It was argued that the core business of the industry, at least in its present and foreseeable future, has more to do with 'provision than development of infrastructure'. Specifically project clients are more accountable for the development of the infrastructure as they decide on how many, the scale, when and where to locate the infrastructure.

Second, the word 'infrastructure' (label 3) was preferred as a generic term that best describes the 'offerings' (services) that the construction industry provides. In the discussion, some delegates wanted the work of their profession or occupation reflected in the mission statement in a more explicit manner, they suggested, for example, replacing the word 'infrastructure' with 'design, construct and maintain'. It was however, resolved that the listing of occupations might exclude instead of including stakeholders. Those who supply items, for example, scaffolding and cranes or those who perform demolition work on some projects, felt may be excluded. In addition, such a listing might make the mission statement too long and turn out to be what Campbell and Yeung (1991) called 'mission impossible'.

Third, the word 'sustainable' was prefixed to underpin three issues: the maintenance and preservation of the infrastructure; the need for the infrastructure to match the social and economic growth needs of Botswana; and the need to protect and preserve the physical environment when executing sector activities.

Fourth, the customer was viewed as the 'social and economic development' (label 2). There was another debate as to whether clients (e.g. public and private sector) should be reflected in the statement. Like before a generic term was preferred to a specific one.

Fifth, the geographical domain was formulated as 'Botswana' (label 4) although some delegates felt the domain should be expanded beyond local borders to include e.g. the southern African region. Proponents of this suggestion felt that although currently a few local companies have actually ventured to obtain work outside the country, the situation may change in the future. However, the debate settled down by focusing on the domestic market.

Lastly, despite the last point, the formulated mission statement was viewed as robust enough to withstand changes in future offerings, geographical domain, or customer base. This was in reaction to what Campbell and Yeung (1991) noted that a narrowly defined mission statement limits future strategic imagination. Kotler (2009) noted by an example of the American Railways where the industry narrowly defined its business as 'railways' instead of 'transport', a mind-set that resulted in the trucking industry eroding their haulage market.

Ssegawa, J (2013) 'Developing a strategic perspective for construction industry of Botswana', Australasian Journal of Construction Economics and Building, 13 (3) 157-172 


\section{Formulating the Vision Statement}

The vision statement was adopted as shown in Figure 3 (based on the components in Table 4 of Section 3.2) but in the context of the local environment.

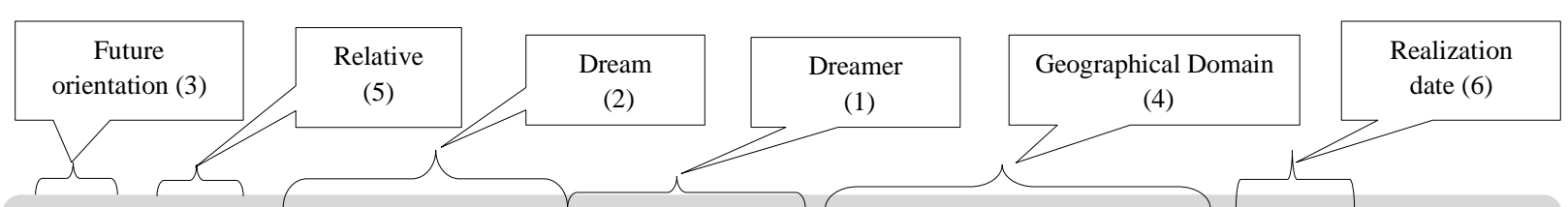

To be the most efficient and effective construction sector in the southern African Region by 2025

Figure 3 A vision statement

First, the dream was coined as 'the most efficient and effective' (label 2) while the dreamer was the 'construction sector' (label 1). Stakeholders referred to efficiency as the manner in which project processes are carried and how it relates to, among others, the metrics of time, cost, quality and risk. On the other hand, effectiveness was viewed as the interface between the project delivery and its impact on the client, user and other stakeholders. The use of the phrase 'efficiency and effectiveness' as the dream, it was argued, should be a culmination of all aspects, for example, having a human resource that is skilled, productive, professional and ethical; and using best practices in (e.g. materials, technology, methods and processes) to deliver services in a well-coordinated and organized manner. It also recognises the need to be customer oriented and socially responsible with the environment. The dream underscores a shift from the current image of the industry which is perceived as deficient in a number of aspects. This is similar to what the Construction 21 Committee of Singapore described their industry as 'dirty, dangerous and demanding' and wanted to turn it into one which is 'professional, productive, and progressive' (Construction 21 Steering Committee, 1999).

Second, the dream was formulated with a future orientation in mind as represented by phrase 'to be' (label 3). In addition, the realisation date of the dream was set as '2025' (label 6) perceived enough time to record change. There was a concern that the realization date of the vision of the sector and national vision i.e. Vision 2016 (Vision Council, n.d.) should be synchronised. The Jamaican construction industry's Vision 2030 (Construction Task Force, 2009), for example, is synchronised with the national vision - Jamaica Vision 2030. It was however, resolved that it would be futile to synchronise the two as nation's realisation date is just too near (2016).

Third, the dream was stated in a relative manner using the word 'most' (label 5) because the performance the 'construction sector' will presumably be compared with other sectors in the identified geographical domain ('southern African Region') (label 4). However, indicators for the comparison will have to be formulated later (in phase four of the reform process). It was noted that though South Africa is the biggest economy in the southern African region, the dream was realistically formulated in the sense that efficiency and effectiveness are not necessarily a function of size of the industry/economy but how well the projects are delivered.

\section{Formulating the Value Statement}

The four components of the value statement were transparency, fairness, zero-tolerance to corruption and ethical behaviour shown in Table $9(\mathrm{a} \& \mathrm{~b})$. The value statement was the most 
understood component of the strategic perspective but also the most debated. The debates centred on the actual number of components to include in the value statement and the semantics of words.

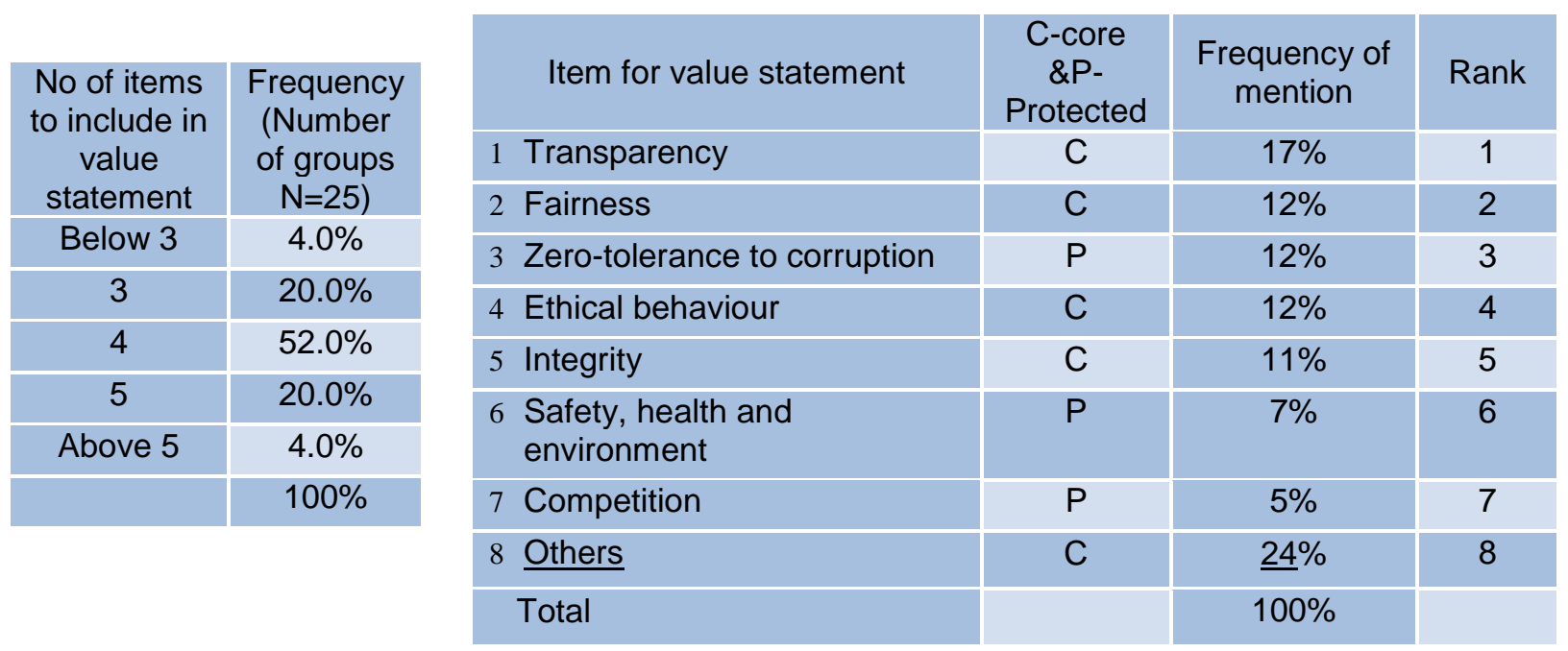

Table 9 Number (a) and list (b) of components formulated for the Value Statement

Majority of the workshop groups (52\%) indicated that there should be four values in the statement and the conference delegates endorsed the decision (see Table 9a). Proponents of this number argued that a balancing act was needed -too many values stand a chance of not being adhered to or even remembered by the industry's stakeholders while too few may not reflect enough values for the industry.

The value of integrity brought most arguments with some preferring it to be on the list. Others argued that it is a loaded term that subsumes other values, for example, fairness, transparency, anti-corruption, ethical behaviour. They argued that including it on the list would mask the seriousness that the industry want emphasise on critical values, for example, fairness.

According to Desmidt, Prinzie and Decramer's (2011) taxonomy, three of the values selected were core and one was a protected value. The first two values were directed to the construction procurement system in Botswana, which stakeholders felt was not transparent and favoured some companies. It was also felt that corruption was on the increase and needed to be reflected in the value statement. This emphasised the notion that values are contextual to the prevailing events in the sector. Desmidt, Prinzie and Decramer's (2011) noted, for example, that the most common values listed by firms in US, in descending order of frequency, are integrity, honesty, respect and diversity. For Norwegian firms it was honesty, respect, integrity and diversity. The two lists differed with Botswana values on the issues of diversity. Perhaps this is due to the homogenous nature of majority of the industry stakeholders.

\section{Formulating the Goal Statement}

The goal statement was formulated around the three components of the balanced scorecard and the additional two identified from literature (see Figure 4). 
i) To increase engagement and collaboration with government (government component).

ii) To create a sustained enabling construction business environment (institutional component).

iii) To develop greater customer focus for infrastructure project delivery (customer component).

iv) To increase and sustain a high level of productivity in the industry (sector processes component).

v) To facilitate the development of an adequate and competent human resource for the industry (learning and development component).

Figure 4 The goal statement

The goals were formulated in order to capture the broad issues that the industry needs to pursue to achieve its vision. It was also argued that in phase three, the goals will be unpacked by generating specific objectives around each goal.

\section{Discussion}

Scholastic frameworks were used to develop a strategic perspective of the construction industry in Botswana summarised in Figure 5.

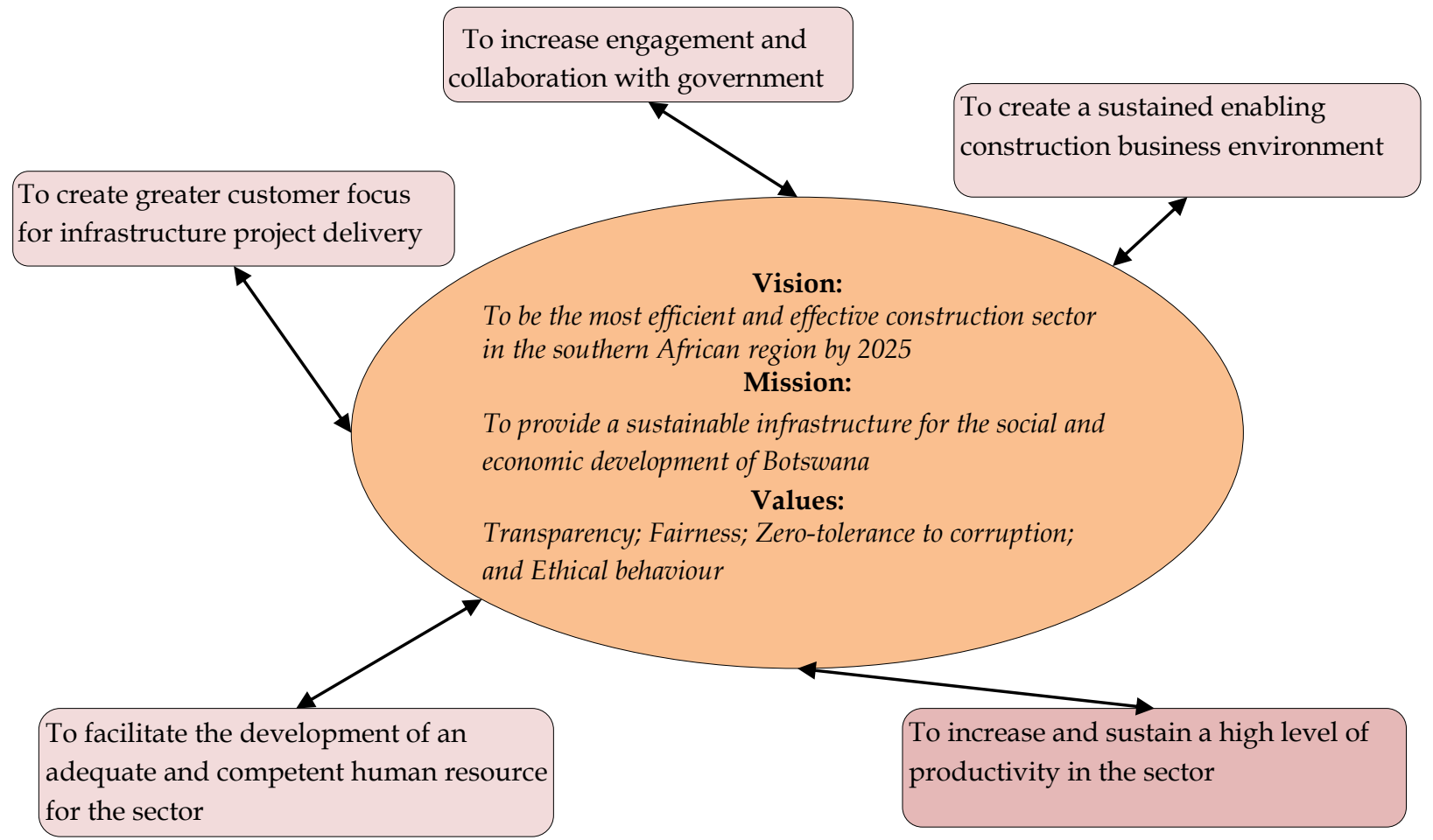

Figure 5 Summary of the strategic perspective

Developing a strategic perspective for the industry provided some challenges including a lack of a common definition, number and content of the statements. Second, was the challenge of reflecting various stakeholder interests in the brief statements especially given the fact that the construction industry is a fragmented sector. Third, was the challenge to formulate a set of statements that would be appealing and yet remain relevant for a substantial period of time.

Despite the challenges, the outcome represented a positive milestone towards reforming the industry. The process gave the stakeholders a chance to reflect on their roles as an industry.

Ssegawa, J (2013) 'Developing a strategic perspective for construction industry of Botswana', Australasian Journal of Construction Economics and Building, 13 (3) 157-172 
Through constructive discussions and debates, stakeholders agreed on a common direction for improving the industry. Stakeholders managed, for once, to identify themselves as a unique set of entities pursuing a common purpose (mission) in terms of the service they offer as a sector (infrastructure) and their customer base (social and economic development of Botswana). They defined what they want to achieve in future (vision - an effective and effective industry); how to achieve it (goals); and how to conduct themselves (values) while conducting business. One delegate provided a mind-set which had besieged the industry by noting '...it was the first time we viewed the industry as a whole. In the past, we were more concerned with solving problems in our sub-sectors to worry about a holistic industry picture. We need to eliminate suspicion and conflict and embrace trust in the sector'. It was noted however, that the strategic perspective was not a panacea of the deficiencies of the industry but a good starting point for the journey to reform. Commitment and coordination shall be required to the take the reforms forward.

\section{Conclusion}

The paper has provided a step-by-step account of how the strategic perspective for the construction industry in Botswana was formulated. The process followed another study which investigated the challenges faced by the industry. The process of formulating the strategic perspective was conducted through a participatory process based on a focus group approach and involved a series of workshops and a national conference in order to adopt the strategic statements that will guide the reform process.

\section{References}

Ansoff, H. I (2007) Strategic Management, Palgrave Macmillan, New York, NY.

Armstrong, G., Harker M., Kotler P., Brennan R. (2009) Marketing: An Introduction, 9 Ed, Pearson, NY.

Baker, M. J. (2007) Marketing Strategy and Management, Palgrave Macmillan, NY.

Balise, J. (2010) China VP visit, envoy defends work, Botswana Guardian, [online], http://www.botswanaguardian.co.bw/newsdetails.php?nid=922\&cat=BG News, (accessed on 20-8-2011).

Bartkus, B. R., Glassman, M. and MacFee, R. B. (2004) A comparison of the quality of European, Japanese and US Mission Statements: A content Analysis, European Management Journal, 22 (4), 393-401.

Bennis, W. G. and Nanus, B. (1985) Leaders: The strategies for taking charge, New York, Haper and Row.

Blumberg, B. Cooper, D. R. and Schindler, P. S. (2005) Business research methods, Berkshire, McGraw Hill.

Campbell, A. and Yeung, S. (1991) Creating a sense of mission, Long Range Planning, 24 (4), 10-20.

CIDB (1994) Construction Industry Development Board of Malaysia, [online] www.cidb.gov.my [accessed on 15 December 2012]

CIDB Act (1984) Singapore Construction Industry Development Act 3 of 1984 [online] http://www.agc.gov.sg [accessed on 15 December 2012]

Construction 21 Steering Committee, Reinventing Construction, Ministry of Manpower and Ministry of National Development, Singapore, 1999

Construction Task Force (2009) Vision 2030 - Construction-Sector Plan 2009-2030, Kingston.

David, F. (1989) How companies define their mission, Long Range Planning, 22 (1), 90-92.

Ssegawa, J (2013) 'Developing a strategic perspective for construction industry of Botswana', Australasian Journal of Construction Economics and Building, 13 (3) 157-172 
Desmidt, S., Prinzie, A., and Decramer, A., (2011) Looking for the value of mission statements: a meta-analysis of 20 years of research, Management Decision, 49 (3), 468 - 483.

Egan, J. (1998) Rethinking Construction: Report of the Construction Task Force, London, HMSO.

Fox P. and Skitmore R. M. (2007) Factors Facilitating Construction Industry Development, Building Research and Information, 35 (2), 178-188.

Giang, D. R. T H., Pheng, L. S. (2011) Role of construction in economic development: Review of key concepts in the past 40 years, Habitat, 35, 118-125.

Hegazy, T. (2002). Computer based construction project management, Prentice Hall, NJ, USA.

Hillebrandt, P.M. (2000) Economic theory and the construction industry, 2ed. MacMillan, Basingstoke.

ILO (1991) Building for tomorrow: International experiences in construction industry development (eds. D. Miles and R. Neale) ILO, Geneva.

ILO (2001) The construction industry in the twenty-first century: its image, employment prospects and skill development, ILO, Geneva

Kaplan, R. S. and Norton, D. P. (1996) Using the balance scorecard as strategic management system, Harvard business review, 74 (1), 75-85.

Kaplan, R. S. Norton, D. P. and Barrows, E. A. (2008) Developing the strategy: Vision, value gaps and analysis, Balanced Scorecard Report, January-February, 3-7

Kemp, S. and Dwyer, L. (2003) Mission statement of international Airline: A content analysis, Tourism Management, 24, 635-653.

Latham, M. (1994) Constructing the team: final report by Sir Michael Latham. Joint Review of Procurement and Contractual Arrangements in the United Kingdom Construction Industry. HMSO, London.

Loosemore, M. (2003) Impediment to reform in the Australian building and construction industry, The Australian Journal of Construction and Economics and Building, 3 (2), 1-8.

Lopes, J. (1998) The construction industry and macro economy in Sub-Sahara Africa post 1970, Construction management and economics, 16 (6), 637-649.

Matejka, K., Kurke, L. B. and Gregory, B (1993) Mission impossible? Designing a great mission statement to ignite your plans, Management Decisions, 34 (4), 31-37.

Mmegi (2008) Corruption in Project Implementation, Editorial, Mmegi Online, available at http://www.mmegi.bw/index.php?sid=9\&aid=28\&dir=2008/January/Friday18 (accessed on 2412-2011).

Morris, R. J. (1996) Developing a Mission for a diversified company, Long Range Planning, 29 (1), 31-37

National Construction Council (2001) The National Construction Council Act of Parliament No.20 of 1979 available at http:www.ncc.or.tz [accessed on 15 December 2012]

Ofori G. (1988) Construction Industry and Economic growth in Singapore, Construction Management and Economics, 6, 57-70.

Ofori, G. (1994) Formulating a long term strategy for developing the Construction Industry in Singapore, Construction Management Economics, 1994, 12, 219-231. 
Palalani, K. (2000) Challenges facing the construction Industry, Proceedings of the $2^{\text {nd }}$ international Conference of the CIB Task Group 29 on construction in developing Countries, 15-1 $7^{\text {th }}$ November, 2000, Gaborone, Botswana, 22-28.

Pearce J A (2009) Strategic Management, 10Ed. McGraw-Hill Education, India.

Pearce, J. and David, D. (1987) Corporate Mission Statements: The bottom line, Academy of Management Executive, 1 (2), 109-116.

Piet, B. (2011) Khama reveals massive rip off at DBES, Mmegi Online, available at http://www.mmegi.bw/index.php?sid=1 aid=813dir=2011/October/Wednesday19\&aid=1314\&dir= 2011/November/Tuesday8 (accessed on 24-12-2011).

Planning Institute of Jamaica (2009) Vision 2030 Jamaica: National Development PlanPlanning for a Secure \& Prosperous Future, Kingston

Porter, M. (1990) The Competitive Advantage of Nations, Harvard Business Review, March April, 73-94

Ramadubu, D. (2010) Police stations investigated, Botswana Guardian, available athttp://www.botswanaguardian.co.bw/newsdetails.php?nid=1470\&cat=BG News (accessed on 24-12-2011).

SA CIDB Act (2000) South Africa Construction Industry Development Act, 2000 [online] Error! Hyperlink reference not valid.205

Sidhu, J. (2003). Mission Statements: Is it time to shelve them?, European Management Review Journal, 21 (4), 103-115.

Smith, J (1998). Building Cost Planning for the design team, Deakin University Press, Victoria, Australia

Ssegawa, J. K. Ntswene, K. and Ngowi, A.B. (2013) Using a situation analysis to identify the construction industry deficiencies in Botswana, Journal of Construction in Developing Countries, 18 (1), 1-18.

Statistics Botswana (2012a) Stats brief: gross domestic product - fourth quarter of 2012, Statistics Botswana available at http://www.cso.gov.bw/index.php?option=com keyindicators\&id=130, accessed on $12^{\text {th }}$ March, 2013

Statistics Botswana (2012b) Stats brief: formal sector employment of June 2011, Statistics Botswana available at:

http://www.cso.gov.bw/index.php?option=com content 1 \&parent $i d=370 \& i d=432 \&$ nid=370, accessed on $12^{\text {th }}$ March, 2013

Thomas, Aridru, Larkai and Monkutlwatsi (2005) Project implementation bottlenecks, Department of Engineering Services, Report, No. PIB/TALM/1, Gaborone.

Turin, D.A. (1973) The Construction Industry: Its economic significance and its role in development 2ed. Building Economics Research Unit, University College London.

Vision Council (n.d.).Vision 2016, the Long-term Vision for Botswana- available at http://www.vision2016.co.bw/tempimg/media/mediac_103.pdf [accessed on 20 June, 2012).

Wells L (1985) The role of Construction in Economic Growth and development, Habitat International, 9 (1), 55-70.

Wong, J M. W., Ng, S. T. and Chan, A. P. C. (2010) Strategic planning for the sustainable development of the construction industry in Hong Kong, Habitat, 34, 256-263.

World Bank (1984) The construction industry: issues and strategies in developing countries, World Bank, Washington.

Ssegawa, J (2013) 'Developing a strategic perspective for construction industry of Botswana', Australasian Journal of Construction Economics and Building, 13 (3) 157-172 